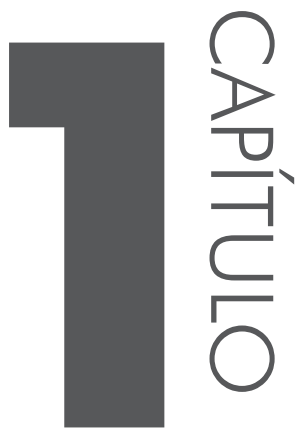

\title{
Ensino de literatura nos anos finais do Ensino Fundamental: reflexões e alternativas
}

Fernanda Müller ${ }^{1}$

"A Educação, qualquer que seja ela, é sempre uma teoria do conhecimento posta em prática." Paulo Freire

\subsection{Introdução}

Nos anos finais do Ensino Fundamental, ensinar literatura tem se mostrado um objetivo secundário ou, no mínimo, alguns gêneros dessa esfera são preteridos em função de outros que se mostrariam mais representativos das atuais

1 Doutora em Literatura pelo Programa de Pós-Graduação em Literatura da UFSC; professora EBTT do Colégio de Aplicação, do Centro de Ciências da Educação, da Universidade Federal de Santa Catarina. Autora do livro Ecos do Oriente: o relato de viagem na literatura brasileira contemporânea. Florianópolis: Mulheres, 2010. Contato: fer.nandamuller@yahoo.com.br. 
práticas sociais, o que leva a questionar o significado da literatura tanto na Educação Básica quanto em nossa sociedade. Afinal, qual papel a literatura ainda pode desempenhar na vida das pessoas? Qual a orientação dos documentos oficiais acerca da formação do leitor e do ensino de literatura nos anos finais do Ensino Fundamental? O que efetivamente se pratica em sala de aula hoje e como podemos repensar uma abordagem do literário mais expressiva para o leitor em formação?

Diante dessa problemática, o presente trabalho propõe uma reflexão sobre as políticas públicas de formação do leitor, ressaltando o processo histórico que resultou na inserção da literatura no currículo escolar da Educação Básica. Em seguida, analisa as aulas de leitura e o diário de leitura, alternativas para contribuir para a formação de jovens leitores, na faixa dos 13 anos, que cursavam o oitavo ano do Ensino Fundamental. Desenvolvido durante os anos letivos de 2013 e 2014, o projeto atendeu 150 educandos de uma escola da rede pública de ensino, em Florianópolis, Santa Catarina. A fim de compreendermos melhor o cenário atual, convém começar olhando para trás.

\subsection{A escolarização da literatura}

A literatura, como sabemos, teve sua trajetória marcada por avanços e retrocessos - entraves e preferências que testemunham os juízos de valor e o prestígio social que lhe foi outorgado ao longo do tempo -, até ser escolarizada e tornar-se componente curricular obrigatório da disciplina de português. Influenciada fortemente por concepções greco-latinas, no Brasil a literatura seria primeiramente estudada atrelada à retórica sob a forma de poética, entre os séculos XVI e XVIII. Nesse período, não custa salientar, o foco maior recaía sobre a gramática, e o ensino do português era apenas um expediente para a alfabetização e posterior aprofundamento na língua e cultura latinas. Somente em 1838, a poética receberia estatuto de componente curricular autônomo, conforme atesta o regulamento do Imperial Colégio Pedro II, no Rio de Janeiro, precursor do que constituiria a nova grade curricular de ensino do português. ${ }^{2}$

2 Inovando a organização do currículo escolar, do Colégio Pedro II saíram as obras que se tornariam referência para o estudo do português por quase um século. A gramática teve como maior representante a obra do professor João Ribeiro, Gramática portuguesa em três volumes (curso elementar, curso médio e curso superior), manual que perdurou no ensino nas primeiras décadas do século XX, e que, em 1941, já estava em sua $97^{a}$ edição para o curso elementar, na $39^{a}$ edição para o curso médio e $21^{a}$ para o curso superior. A literatura de então seria praticada como postulado na obra de Fernandes Pinheiro, as Postilas de retórica e poética ditadas aos alunos do Imperial 
Influenciados pela instituição carioca, à época referência em ensino, norma e estilo seguiriam apartados por um longo período, como evidenciam os manuais lançados por volta da metade do século XX. Publicados em volumes distintos, eram empregados em sala para o estudo da gramática ou da literatura mediante coletâneas de autores consagrados e seus clássicos. ${ }^{3}$ Entre os anos de 1950 e 1960, ocorre uma importante fusão: texto e tópico gramatical passam a ser, pela primeira vez, organizados em unidades temáticas, apesar da primazia da gramática sobre o texto ainda persistir. Mais radical seria a mudança instituída por decreto nas décadas seguintes, com a implantação da nova Lei de Diretrizes e Bases da Educação (Lei no 5.692/71). Diferente dos processos anteriores, decorrentes de transformações sociais e culturais ocorridas ao longo do tempo, houve a imposição de nova abordagem pedagógica por parte do governo brasileiro pós-golpe civil-militar de $1^{\circ}$ de abril de 1964 .

A educação foi posta a serviço dos interesses ideológicos do regime e do mercado que lhe davam suporte, como esclarece Demerval Saviani (2008). Resulta daí que convivamos na atualidade com o legado deixado pela ditadura: o fortalecimento do ensino profissionalizante, o favorecimento da privatização do ensino e a implantação da pós-graduação a partir da estrutura organizacional americana e da experiência universitária europeia (SAVIANI, 2008). No que se refere mais especificamente ao ensino da língua portuguesa, merece nota como esta passou a ser considerada instrumento para o desenvolvimento nacional. E aqui teríamos a maior das separações entre língua e literatura.

Se antes a leitura de clássicos, com aprofundamento teórico maior ou menor da poética e da retórica, fazia parte tanto do repertório do ginásio quanto do secundário, ainda que em alguns períodos submetida aos estudos gramaticais e em níveis distintos de compreensão, agora no $1^{\circ}$ grau as escolas são obrigadas a ensinar comunicação e expressão nas séries iniciais; comunicação em língua portuguesa nas séries finais; e língua portuguesa e literatura brasileira no antigo $2^{\circ}$ grau (SOARES, 2002). Em outras palavras, a literatura praticamente

Colégio Pedro II pelo respectivo professor, de 1877; e na de Franklin Dória, a Tese para o concurso da cadeira de retórica, poética e literatura nacional do externato do Colégio Pedro II, de 1878 (BRANDÃO, 1988, p. 43-58).

3 Organizadas de modo independente como manuais didáticos, temos as gramáticas e as coletâneas de textos, como atestam O português prático, de José Marques da Cruz, com 166 mil exemplares vendidos em 1955 e a Gramática metódica da língua portuguesa, de Napoleão Mendes de Almeida, com 90 mil exemplares impressos até o início dos anos 1960. Em sala, tais obras eram intercaladas com a Selecta nacional, do filólogo português Caldas Aulete e, especialmente, a Antologia nacional, de Fausto Barreto e Carlos de Laet, que dominaram as escolas brasileiras por mais de 70 anos com sua concepção canônica de literatura (SOARES, 2002, p. 163-166). 
saiu do currículo do Ensino Fundamental para ser concentrada no que hoje nomeamos Ensino Médio.

Marcada pela visão desenvolvimentista, para instituírem a língua como instrumento, os militares e seus apoiadores encontraram suporte na teoria da comunicação, em ascensão na década de 1970. Desse modo, a língua passou a ser tratada como sistema, visão amparada pela psicologia, filosofia e sociologia de então, o que fez com que a concepção de expressão estética, abordada desde os estudos da retórica e da poética, cedesse lugar à concepção de língua como comunicação. De modo pragmático e utilitário, o professor deveria preparar o alunado para desenvolver e aperfeiçoar os comportamentos de emissor e receptor de mensagens em seus diversos códigos, verbais e não verbais. Nas palavras de Soares (2002, p. 169, grifos do autor): “já não se trata mais de estudo sobre a língua ou de estudo da língua, mas de desenvolvimento do uso da língua”.

Houve outra importante mudança no período: o abandono da escolha de textos por critérios exclusivamente estéticos devido à ampliação do conceito de leitura. Observando a intensidade da presença social dos textos, permitiu-se a inclusão na esfera escolar de jornais e revistas, HQ, publicidade e humor, especialmente no $1^{\circ}$ grau, no qual os textos das esferas não literárias passariam a dominar a paisagem, restando da literatura quase que exclusivamente a crônica. Apesar das transformações, ao final de uma década da nova pedagogia, o conceito de literatura em si mantinha-se quase inalterado: o habitual cânone universal, eurocêntrico e masculino persistia, e a literatura continuava a ser ensinada como obra de grandes homens portugueses e expoentes brasileiros ainda que agora mais salpicada de verde-amarelo, bananeiras, coqueiros e sabiás -, defendida como expressão elevada da língua, herança cultural e orgulho nacional. Tratamento tão solene permite compreender porque a literatura foi postergada aos secundaristas: o objetivo de ensiná-la não era mais aprimorar a percepção da língua ou da sociedade, mas elevar monumentos, colaborar para construir simbolicamente uma nação.

Acresçamos, a seu turno, a depreciação da carreira docente que marcou essas mesmas décadas, em que professores passaram a ser olhados com cautela, quando não com desconfiança. Especialmente nos grandes centros urbanos, onde não raro eram vigiados, fichados e exonerados caso organizassem protestos ou desrespeitassem as orientações ideológicas do regime, estas sim, única forma de exercer patriotismo. Período de controle em que, não por acaso, testemunhamos o início da política de universalização do livro didático nas redes públicas de ensino a par e passo com as apostilas nas redes privadas. Estratégia de sucesso porque, historicamente, foi influenciada e influenciou o boom da indústria gráfica. 
Observando o material produzido, não é de se estranhar que Osman Lins o tenha caracterizado na década de 1970 como "uma Disneylândia pedagógica" (LINS, 1977). Profusamente ilustrados e coloridos, exagerados na abordagem e na apresentação, os resquícios mantêm-se visíveis em uma parcela dos livros didáticos produzidos ainda hoje, em que a poluição visual das páginas mais perturba do que atrai o leitor. Osman Lins critica com veemência o desserviço à literatura brasileira prestado por estas primeiras décadas de livros didáticos, em prol do lucro fácil do novo comércio. Para o autor, eram um arrazoado de "páginas artificiais, sem nexo com a realidade, com os problemas cotidianos do povo, ou os dilemas eternos do homem" (LINS, 1977, p. 18). “Anedotário de desonestidades" que iam de exercícios tolos com uma linguagem forçada, algo como "Oi! Eu sou a vírgula, você já me conhece?", até a inclusão de textos claramente amadores do próprio autor do compêndio.

Enquanto as páginas eram preenchidas dessa forma, a produção literária de importantes autores do período era suprimida. O criador de Avalovara enumera, inclusive, alguns de seus contemporâneos marginalizados, o que nos permite ter uma dimensão do problema. Afinal, os livros adotados pelo regime não apresentavam aos alunos a obra de escritores como Ciro dos Anjos, Guimarães Rosa, Aníbal Machado, João Cabral de Mello Neto, Graciliano Ramos, Jorge Amado, Autran Dourado e Lucio Cardoso, entre tantos outros. ${ }^{4}$ O próprio Osman Lins, escritor premiado, mas militante engajado na defesa dos direitos humanos, da liberdade de expressão e da justiça social, como não é difícil supor, era igualmente excluído.

Não podemos deixar passar ao largo, nesse ínterim, a manchete que anualmente é estampada na primeira página de jornais, ratificando que o governo brasileiro persiste como o maior comprador de livros do mundo. Algumas obras de literatura, dicionários e outros materiais de referência começaram a chegar às escolas nos últimos anos, adquiridas por meio do Fundo Nacional pelo Desenvolvimento da Educação (FNDE), mas em número inexpressivo. O foco do programa são os livros didáticos, repensados e reelaborados nas perspectivas teórica e metodológica desde o fim do regime ditatorial, mas ainda hoje impostos como modelo de ensino, cuja compra anual ultrapassa a cifra de um bilhão de reais. ${ }^{5}$ Como seria o ensino no Brasil se o FNDE optasse por uma

4 Wladimir Garcia (2005) faz uma leitura do trabalho do escritor educador.

5 O governo brasileiro está sempre comprando livros didáticos: um ano para os anos iniciais, no seguinte para os finais, logo depois para o Ensino Médio e, então, volta para os anos iniciais e se repete o ciclo. Isso, sem falar nos livros didáticos voltados ao EJA, aos cursos profissionalizantes e à educação no campo. No Brasil, esse material é substituído a cada três anos, independentemente de suas condições e das práticas escolares já estarem contempladas. De acordo com os dados fornecidos 
política centrada na distribuição massiva de material integral - literatura, dicionários e obras de referência -, com a vantagem de não prescreverem a cada três anos? Não resta dúvida de que se optou por um modelo mercadológico em que a adoção de livros didáticos e didatizantes sobrepõe-se a um plano de carreira para o magistério com condições dignas e diferenciadas de trabalho. Trata-se, antes de tudo, de uma escolha, uma opção política e não financeira, com a qual arcam alunos, docentes e a sociedade como um todo.

Bem é verdade que o processo de desvalorização dos docentes data de fins da década de 1950, quando o professor erudito, que exercia domínio sobre a turma e era investido de um poder simbólico socialmente legitimado, começa a ser escolhido nas massas para ensinar as massas, que agora passam a ocupar os bancos escolares. Jornada extenuante, salas superlotadas, com pouco ou nenhum tempo destinado em seu plano de trabalho para planejar e estudar. Isso tudo empregando o material didático que, como discutido, era mal-elaborado e excludente, cabendo-lhe apenas seguir o roteiro do autor. Nada mais conveniente a um regime ditatorial e opressor. Lastimável, mas ao mesmo tempo sintomático, é o fato dessa política pública de ensino persistir, muito bem aparelhada por uma indústria editorial faraônica. Não surpreende, portanto, que as licenciaturas estejam entre os cursos universitários menos procurados e sejam cursados, em geral, por alunos que pertencem a famílias com menores índices socioeconômicos.

Resistindo, apesar do controle, opressão e mercantilismo, os professores rejeitaram as concepções de língua e ensino de língua impostas durante o golpe. Assim, em 1980, com a redemocratização do país, foi abandonada a concepção utilitária de ensino em favor de novas teorias desenvolvidas na área das ciências linguísticas, que passam a influenciar a disciplina, novamente denominada português. ${ }^{6}$ A partir desse período e, mais intensamente, com a virada do século XX, o filósofo da linguagem Mikhail Bakhtin passa a exercer maior influência na concepção de ensino. Sua teoria dos gêneros do discurso

pelo site do FNDE (DADOS, 2015), no ano de 2014 foram comprados mais de 137.858.058 (cento e trinta e sete milhões, oitocentos e cinquenta e oito mil e cinquenta e oito) exemplares de livros didáticos, computados aí somente os exemplares destinados para o Ensino Fundamental e Médio. Tal compra acarretou em uma despesa com aquisição e distribuição de R \$ 1.212.945.073,00 (um bilhão, duzentos e doze milhões, novecentos e quarenta e cinco mil e setenta e três reais).

6 Magda Soares esclarece que, influenciados pela linguística, sociolinguística, linguística textual, semântica, pragmática, teoria da enunciação e análise do discurso, o ensino de português passa a ser repensado. No que se refere mais especificamente à abordagem da literatura, a autora também chama a atenção para a influência que sobreveio das áreas da história, da sociologia e da antropologia da leitura e da escrita, que têm forçado uma reflexão sobre as práticas de leitura atuais e do passado e sobre a circulação social dos gêneros, suas funções e usos (SOARES, 2002, p. 171-174). 
confere outros significados à abordagem dos textos de diversos extratos sociais inseridos agora nas práticas escolares. Voltando-se a uma compreensão maior, Bakhtin valoriza as esferas de circulação e os interesses dos sujeitos implicados no discurso, sem relegar a carga expressiva a uma forma padrão. Desse modo, ainda que dentro de círculos literários mais estreitos, obras como Marxismo e filosofia da linguagem (1929-1930), A cultura popular na Idade Média e no Renascimento: o contexto de François Rabelais (1940) e Estética da criação verbal (1979) não passaram despercebidas.

\subsection{Os documentos oficiais e o ensino de literatura na atualidade}

A leitura de Bakhtin influenciou, ou, melhor dito, norteou, a concepção dos Parâmetros Curriculares Nacionais, os PCN, para o estudo do português. Publicados em 1998 - ou seja, pouco mais de um ano após promulgada a atual LDB, a Lei $\mathrm{n}^{\circ}$ 9.394, de 20 de dezembro de 1996, que veio para substituir a instituída pela ditadura -, os PCN foram considerados progressistas e inovadores, posto que refletiam discussões em ebulição nos cursos de licenciatura, posteriormente complementadas e revistas quando da publicação dos Parâmetros Curriculares Nacionais: Ensino Médio, o PCNEM (2000), e, especialmente, dos Parâmetros Curriculares Nacionais: Ensino Médio+, o PCNEM+ (2007). Entre seus postulados mais importantes no que se refere ao ensino de português, merece destaque o que firma que "pela linguagem se expressam ideias, pensamentos e intenções, se estabelecem relações interpessoais inexistentes e se influencia o outro, alterando suas representações da realidade e da sociedade e o rumo de suas (re)ações" (BRASIL, 1998, p. 20).

Além disso, o documento, que busca servir de referência para discussões curriculares nas diversas áreas do conhecimento, indica no volume voltado ao ensino de português que os textos a serem empregados em sala deveriam ser trabalhados de modo integrado e selecionados por suas características e usos. Deveriam ser tomados, portanto, aqueles textos que pudessem favorecer a reflexão crítica, o exercício de formas de pensamento mais elaboradas e abstratas, bem como a fruição estética dos usos artísticos da linguagem. Como sintetizado no texto oficial, trata-se de escolher "os mais vitais para a plena participação numa sociedade letrada” (BRASIL, 1998, p. 24).

O trabalho com fragmentos desconectados e simplificados é condenado pelos PCN, que fazem uma severa crítica aos que confundem a capacidade do aluno de interpretar e produzir discurso com a capacidade de ler e escrever sozinho. Apesar dessas orientações amplamente respaldadas pela academia, o ranço da visão utilitária exposta páginas atrás se faz sentir na prática, na 
qual a abordagem isolada de gramática e literatura, ou mesmo de escrita e leitura como coisas distintas ainda não foi eliminada de todo. Há escolas cuja organização curricular desconhece o postulado pelos PCN, uma vez que segmentam o ensino de português entre língua (= gramática), literatura (= periodização literária, com uso de trechos de obras) e produção (= elaboração de redações, com ênfase em dissertações). Em algumas dessas instituições - e nem precisamos sair de Florianópolis para nos depararmos com tal concepção ultrapassada, em especial na rede particular de ensino -, mantêm-se, inclusive, a prática de contratar mais de um professor para esse fim: são dois ou três profissionais, cada um responsável por dissecar uma faceta da língua de modo isolado.

Tendo em vista que boa parte das crianças e jovens brasileiros encontram na escola o único espaço que lhes pode proporcionar o contato com textos escritos que se converterão futuramente em seus modelos para a produção, as condições adequadas para o ensino-aprendizado deveriam ser asseguradas a todos. Mas quais textos podem ser empregados de modo a não repisar práticas superadas? O que é representativo da sociedade letrada brasileira contemporânea? Qual lugar cabe hoje à literatura no Ensino Fundamental? A resposta dos PCN é apresentar, como modelo de textos relevantes para a inserção social de crianças e jovens, o trabalho com variados gêneros do discurso, a saber: notícia, editorial, carta argumentativa, artigo de divulgação científica, verbete enciclopédico, conto, romance, entre outros.

Contrariando o fato de os dois gêneros da esfera literária citados serem enumerados por último, os idealizadores do documento concedem alguma ênfase à especificidade do texto literário. De acordo com os PCN, a literatura constitui uma forma peculiar de representação e estilo em que predominam a força criativa da imaginação e a intenção estética. Portanto, deixam claro que não se trata de mera fantasia que nada tem a ver com o que se entende por realidade, nem de puro exercício lúdico sobre as formas e sentidos da linguagem e da língua. Reproduzindo as palavras contidas nos PCN, literatura corresponde a:

um inusitado tipo de diálogo regido por jogos de aproximação e afastamento, em que as invenções da linguagem, a instauração de pontos de vista particulares e a expressão da subjetividade podem estar misturadas a citações do cotidiano, a referências iniciais e, mesmo, a procedimentos racionalizantes. Nesse sentido, enraizando-se na imaginação e construindo novas hipóteses e metáforas explicativas, o texto literário é outra forma/fonte de produção/apreensão de conhecimentos (BRASIL, 1998, p. 26-27). 
A abordagem dos PCN volta-se, no restante do documento, a uma descrição de conceitos e procedimentos de leitura, remetendo ao termo literatura apenas em trechos específicos, por vezes um tanto isolados. Mais do que literatura, conferem destaque à formação de leitores, cujo papel de destaque seria do terceiro e quarto ciclos do Ensino Fundamental. Afinal, segundo os PCN, é no interior destes que muitos alunos ou desistem de ler por não conseguirem responder às demandas de leitura colocadas pela escola, ou passam a utilizar os procedimentos construídos nos ciclos anteriores para lidar com os desafios impostos pela leitura, com autonomia maior (BRASIL, 1998, p. 70).

Os objetivos a serem atingidos pelos alunos nas diversas áreas do conhecimento são traçados pelos PCN de modo bastante claro. Na área de linguagens, particularmente do ensino de português, para os quatro últimos anos do Ensino Fundamental, é explicitado que este deveria organizar-se de forma a garantir ao aluno a apropriação e o desenvolvimento da linguagem oral e da linguagem escrita, detalhando a segunda. Uma vez que a política de ensino nacional reforça a do livro didático, gostaria de comparar o postulado pelos PCN no que se refere ao emprego de diversos gêneros do discurso, entre os quais os da esfera literária, ao trabalho proposto pelos livros didáticos. Tomando inicialmente como referência o Guia de livros didáticos: PNLD 2014 (BRASIL, 2013), notamos que os objetivos reproduzidos em suas orientações são rigorosamente transcritos dos PCN.

Das 23 coleções encaminhadas para avaliação no último PNLD, apenas 12 foram aprovadas, ou seja, cerca de 50\%. Todavia, mesmo nos livros aprovados as análises elaboradas pelos avaliadores das coleções presentes no Guia revelam que a importância da fruição estética e o destaque concedido à literatura brasileira não são plenamente contemplados. A própria inclusão de textos de natureza literária de modo mais equilibrado com textos dos demais gêneros discursivos é apontada como algo recente no Ensino Fundamental. Em sua análise, os consultores ponderam que, de um modo geral, todas as coleções apresentavam coletâneas minimamente representativas do que a cultura da escrita oferece a um adolescente, mas deixam claro que as esferas mais contempladas são a jornalística e/ou midiática, seguida da produção de conhecimentos especializados, na forma da divulgação científica e de obras de referência como enciclopédias e dicionários. Por último, vêm os textos de natureza literária, aí incluída tanto a literatura infantojuvenil e adulta quanto a brasileira e a estrangeira, embora sua abordagem varie consideravelmente de uma coleção para a outra.

Tomando como referência a terminologia empregada no Guia e observando os gêneros mais abordados nas coleções avaliadas, elaboramos o seguinte quadro: 
Quadro 1.1 - Gêneros do discurso abordados pelos livros didáticos selecionados pelo PNLD 2014 (Língua portuguesa - anos finais do Ensino Fundamental)

\begin{tabular}{|c|c|}
\hline $\begin{array}{c}\text { Gêneros } \\
\text { jornalísticos }\end{array}$ & $\begin{array}{c}\text { carta do leitor, depoimento, editorial, perfil, notícia, reportagem, } \\
\text { resenha crítica, sinopse, artigo de opinião, primeira página de } \\
\text { jornal, entrevista, texto de divulgação científica, texto informativo }\end{array}$ \\
\hline $\begin{array}{c}\text { Gêneros } \\
\text { midiáticos }\end{array}$ & $\begin{array}{r}\text { guia de viagem, anúncio, roteiro (de filme, turístico, de estudo), capa } \\
\text { (de livro, de DVD), orelha de livro, prefácio de livro, radionovela, } \\
\text { comunicado, carta, seminário, comunicação oral, exposição de } \\
\text { trabalho, negociação de compra e venda, debate, verbete }\end{array}$ \\
\hline $\begin{array}{c}\text { Gêneros } \\
\text { multimodais }\end{array}$ & $\begin{array}{c}\text { cartaz, gráfico, mapa, HQ, tirinha, cartoon, charge } \\
\text { Gêneros } \\
\text { imagéticos }\end{array}$ \\
\hline $\begin{array}{c}\text { Gêneros } \\
\text { literários }\end{array}$ & $\begin{array}{c}\text { narrativa de terror, poesia, haicai, acróstico, letra de música, rap, } \\
\text { crônica, cordel, memórias, literatura, cena de peça, diário }\end{array}$ \\
\hline
\end{tabular}

Fonte: Brasil (2013).

Embora a divisão, grosso modo, em cinco grupos de gêneros seja passível de discussão, ela permite algumas análises. Apesar de cerca de $23 \%$ dos gêneros pertencerem à esfera da literatura contra $77 \%$ das demais áreas, não podemos chegar a estatísticas relevantes apenas por meio desses dados, tendo em vista que alguns gêneros, como gráfico e negociação de compra e venda, estão presentes em poucas coleções, enquanto anúncio, HQ, notícia, reportagem, roteiro de filme, conto, crônica e poesia são contemplados praticamente pela totalidade das coleções.

Em comum nos livros didáticos analisados, temos a adoção de textos de menor extensão. Miniconto, poesia e letra de música nem sempre são explorados como gênero, muitas vezes são pretexto ou provocação para contextualizar a temática na abertura do capítulo ou um extra nos exercícios de interpretação de textos de outra natureza. Cabem em qualquer cantinho da folha e, às 
vezes, nem se compreende muito porque estão ali. Com a literatura de cordel o cenário é ligeiramente diferente: temos reproduções na íntegra, como temos também adaptações ou fragmentos do original, algo desnecessário tendo em vista o tamanho mais ou menos regular e curto dessas obras. Mito, lenda, fábula, cordel, conto, crônica e memórias, pela diversidade de autores e de temas abordados, mostram-se os gêneros literários mais bem explorados nos livros didáticos voltados aos anos finais. Como são textos mais curtos ou mais passíveis de fragmentação em capítulos, permitem a inserção na íntegra e costumam ser abordados em projetos mais extensos que vão da leitura à interpretação, análise linguística e produção.

O problema maior mostra-se com relação aos gêneros literários longos, praticamente banidos dos livros e, por conseguinte, dos anos finais. Obviamente os livros didáticos não poderiam incluir a reprodução de romances em sua versão integral no modelo editorial adotado. Assim, ainda que não constitua uma proposta sistematizada de trabalho, em muitas coleções há a indicação de obras para leitura em todas as unidades, com a reprodução da capa e pequena biografia do autor. Na maioria das vezes, é mais uma sugestão de leitura do livro do qual foi extraído o texto em análise ou de outra obra de autor citado na unidade ou de obra que aborda a temática tratada naquela unidade. Também há uma lista de títulos, filmes e músicas na abertura de cada unidade, em algumas coleções. Uma vez que se trata de uma listagem mais ou menos articulada a depender da coleção, cabe ao professor colaborar para significá-la junto aos alunos.

Nota-se, portanto, que ainda mais do que ocorre com outros gêneros, para o trabalho com textos longos é fundamental ultrapassar as páginas do livro didático, corroborando para o estímulo à leitura, à compreensão e à apropriação da obra, empregando os materiais que a biblioteca da escola, a comunidade e as famílias dos alunos dispuserem. Caso contrário, o leitor de literatura infantil não encontrará estímulo para prosseguir nem na literatura infantojuvenil nem na literatura brasileira ou estrangeira voltada ao público em geral ao chegar a esse segmento. De muitas escolas vem o relato de que, após a conclusão dos Anos Iniciais, quando não há mais professores regentes e existe outra dinâmica em sala, cessam as visitas à biblioteca e, com elas, o mundo de possibilidades que é próprio desse espaço/tempo. ${ }^{7}$

7 Entre os livros didáticos aprovados pelo MEC (BRASIL, 2013), somente a série Universos: Língua Portuguesa, de Rogério de Araújo Ramos e Márcia Takeuchi (SM, 2012), propõe o trabalho com romance, e, ainda assim, trata-se de um projeto anual para a leitura de um título. Em se tratando de teatro a situação tampouco melhora. A série Português: uma língua brasileira, de Regina Figueiredo Horta, Lígia Menna e Graça Proença (Leya, 2012), sugere o trabalho com uma cena de peça de teatro. Caso seme- 
Assim, falta promover a leitura de textos maiores e mais complexos, chamando a atenção para o trabalho estético e a existência de sistemas de obras, autores, público leitor e crítica. Nesse sentido, romances, epopeias e dramas, exatamente os gêneros literários mais excluídos, são os mais propícios a tais explorações, tendo em vista o trabalho estético e a fruição literária que podem ser apreciados ao longo de um volume maior de texto, com o envolvimento subjetivo do leitor com a obra, sua identificação pessoal com personagens e tramas, a repercussão da publicação, o contexto social no qual estão imersos, os paralelos com outras obras do gênero produzidas no mesmo período ou em diversas fases.

\subsection{As aulas e o diário de leitura: possibilidades de intervenção}

Em escolas que possuem um perfil de alunos bastante heterogêneo, observamos que os alunos que se tornam leitores fluentes ao final do Ensino Fundamental vêm de famílias com pais letrados ou conseguem superar com algum ímpeto particular as adversidades em algumas instituições de ensino, não devido a elas, mas apesar delas. Promover uma ponte entre o fascínio pela literatura infantojuvenil e o desgosto diante de uma literatura adulta para não iniciados foi a motivação inicial desse projeto, visando colaborar para a formação de leitores críticos, com algum repertório que sinalize a formação de um cânone particular de gostos.

Muito mais do que a leitura mecânica, o docente ou, melhor dizendo, a escola como um todo, em suas diversas disciplinas, profissionais e espaços, precisa estimular a leitura de mundo, conforme Paulo Freire a denominou, para, na soma das duas, atingir o que tomamos aqui por leitura crítica (SILVA, 2009, p. 23-40). De acordo com Nara Caetano Rodrigues, aprender a ler é um processo permanente que pode até não se iniciar na escola, mas que não pode deixar de ser desenvolvido no espaço escolar, uma vez que pressupõe também habilidades (conteúdos) que são da competência escolar (RODRIGUES, 2007, p. 218-219). A pesquisadora enfatiza a maneira como a escola constantemente cobra os resultados da leitura, o seu conteúdo, mesmo que, na maioria dos casos, pouco se dedique a ensinar a ler, fornecendo métodos, orientação e tempo.

Ora, torno a insistir, como estabelecer objetivos mais claros, se programas e ementas são moldados por escolas ou determinados por livros didáticos abstratamente para todos e, consequentemente, para nenhum indivíduo real? Aceitar o desafio de promover a leitura e a escrita de modo pleno é resistir contra

lhante ao da série Singular e plural: leitura, produção e estudos da linguagem, de Laura de Figueiredo, Marisa Balthasar e Shirley Goulart (Moderna, 2012). 
um sistema opressor e alienante que prega uma leitura superficial e a cada dia mais fragmentada, como vemos circular nas redes sociais. É ensinar a ler nas entrelinhas da mídia. Do mundo. Significa, em última instância, reconhecer que letramento é militância, é resistência.

\subsubsection{Apresentação do projeto}

Há três anos foram concebidas práticas para repensar o ensino de leitura e de literatura junto aos alunos do $8^{\circ}$ ano do Ensino Fundamental, muito embora esta análise dedique-se especialmente aos resultados obtidos nos anos de 2013 e 2014. Cabe salientar que, como não poderia deixar de ser, mais do que uma proposta pedagógica, trata-se de uma proposta política de ensino-aprendizagem com base em ações que foram norteadas, invariavelmente, por leituras e reflexões que partiram da convivência com os alunos, do conteúdo que se pretendia desenvolver e do convívio com outros professores, colegas da série com os quais foram realizadas experiências de cunho transdisciplinar, especialmente com as disciplinas de história, estudos latino-americanos, geografia e ciências.

O primeiro passo foi propor aos alunos que uma das aulas semanais de português passasse a acontecer na biblioteca escolar e fosse destinada exclusivamente a práticas de leitura. Batizada pelos alunos de "aula de leitura", as primeiras semanas costumam ser marcadas por maior movimentação e conversas paralelas, mas com o tempo os próprios alunos passam a exigir silêncio dos demais e a concentração aumenta. Talvez ainda maior do que a dispersão promovida por colegas seja a resistência em desapegar-se de celulares durante o tempo de leitura: manusear os livros ou dispositivos digitais de leitura sem fones de ouvido com música alta e, ao mesmo tempo, controlar o ímpeto de checar mensagens tão logo as recebam. Um número considerável de alunos afirma estar habituado a ser atravessado por outras vozes e discursos incessantemente, posto que quase a totalidade dos adolescentes que participaram desse projeto - mas não só eles - mantêm-se conectados a maior parte do tempo. Um considerável desafio das aulas de leitura é estimular a concentração, focando em uma única atividade durante sua realização.

Além da leitura individual, foram instituídas leituras coletivas de contos longos e até mesmo de alguns romances menos extensos. Nessas aulas, a professora ou outro aluno mais fluente assume o papel de narrador e cópias com as falas grifadas são distribuídas entre alunos que se dispõem a incorporar as personagens, independentemente do gênero daqueles e destas. Usam alguns acessórios simples para caracterizar-se em determinado papel, como um lenço, cocar, chapéu, avental ou colares. Esse foi o caso da leitura de contos como De quanta terra precisa um homem?, de Liév Tolstói, O gato preto e Manuscrito encontra- 
do em uma garrafa, de Edgar Allan Poe e os romances Vida de droga, de Walcyr Carrasco, e O preço do consumo, de Ivan Jaf e Daniela Palma, lidos integralmente nos grupos, visando a discussão para trabalhos em parceria com outras disciplinas. A mesma abordagem é empregada com os primeiros capítulos de livros que posteriormente deverão ser lidos pela turma toda individualmente, como já ocorreu com Aprendiz de inventor, de Carrascoza, Jogos vorazes, de Suzanne Collins, e 1984, de George Orwell.

Em um período que varia de acordo com o andamento das atividades, são realizados encontros para a socialização do que foi/está sendo lido. Nessas ocasiões, os próprios alunos, em círculo, comentam e recomendam ou não a leitura deste ou daquele livro aos demais. Reforça-se, com tal atividade, a constituição de uma comunidade de leitores em cada turma, conforme discutido por Rildo Cosson (2014) na obra Círculos de leitura e letramento literário. As avaliações e indicações costumam estimular outros a ler, pois destacam o que mais gostaram, não raro levando trechos e fazendo defesas inflamadas. Na ocasião, além da formação de uma roda, a atividade transforma-se em um jogo com a simples inserção de um boneco - um dragão de pelúcia com um livro na mão, mas poderia ser qualquer outro objeto, como um estojo ou até uma bola de papel-que é lançado de mão em mão e que determina quem será o próximo a comentar o que leu. $\mathrm{O}$ volume de livros lidos aumentou exponencialmente e a indicação dos colegas motiva mesmo os mais desacreditados, pois as leituras começam a criar vínculos de identificação no grupo.

Faltava, no entanto, articular juntamente às práticas de leitura alguma forma de escrita cotidiana, de modo a incorporar a escrita à rotina de cada um. Assim, de maneira paralela e complementar, no início do ano letivo de 2013 os alunos foram desafiados a elaborar diários de leitura: um caderno no qual registrariam uma vez por semana o que mais chamou sua atenção entre tudo o que foi lido. A orientação inicial era que desenvolvessem um breve relato do que leram, a citação de fontes consultadas e um posicionamento pessoal/crítico diante do tema/obra. Aos poucos, esse registro das impressões de leitor ganhou naturalmente novas formas de expressão, tendo em vista as experimentações dos envolvidos no processo.

Cosson (2014) destaca o diário de leitura como uma das possibilidades de acompanhar e significar as experiências de leitura, ao lado da dramatização, do fandom (fanfiction), do RPG e da resenha. Nas palavras do autor, que promove uma reflexão especificamente sobre esses gêneros de escrita:

O diário de leitura é um registro das impressões do leitor durante a leitura do livro, podendo versar sobre dificuldades de compreensão de determinadas palavras e trechos, transcrição de trechos favoritos com observações, evocação de alguma vivência, relação 
com outros textos lidos, apreciação de recursos textuais, avaliação da ação das personagens, identificação de referências históricas e outros tantos recursos que constituem a leitura como um diálogo registrado entre leitor e texto (COSSON, 2014, p. 122).

Num primeiro momento, o diário era recolhido ao final de cada trimestre para acompanhamento, recebendo comentários e observações. No entanto, havia dois problemas: o primeiro era que alguns alunos não compreendiam a proposta, limitando-se a copiar trechos aleatórios sem maior significação, não raro às vésperas da entrega. $\mathrm{O}$ segundo era que a prática acarretava um volume gigantesco de material para ser lido a cada rodada. A solução encontrada foi solicitar que levassem o diário nas aulas de leitura semanalmente. Assim, enquanto os alunos leem seus livros, é possível acompanhar o que registraram naquele período: orientar melhor os que não se soltaram na escrita, por não entender a atividade ou não se dedicar suficientemente; indicar livros que tenham relação com as preferências individuais dos alunos, especialmente para aqueles cujo problema não é a escrita, mas a leitura; comentar as experiências relatadas e compartilhar as próprias percepções sobre o tema/obra. Transcrevo a seguir alguns exemplos de comentários e orientações retirados de diversos diários dos alunos:

- E qual é esse livro 'baita' que você falou?

- Que bom que está curtindo tanto!

- Não conheço ainda...

- Já me falaram, está na minha cabeceira à espera de tempo... tenho uns 11 na fila!

- Nossa, que enredo original, não é?! Pelo menos as personagens surpreendem?

Boa sorte, vão precisar!

- Fico superfeliz que esteja gostando: torço para que se divirta e conclua a leitura! Aprendiz de inventor foi um dos meus livros preferidos de 2015: uma saga sem cadáveres e que nos faz pensar...

- Acho que essa busca pela verdadeira identidade tem tudo a ver com os dramas dessa tua fase da vida: na adolescência paramos para pensar pela $1^{\text {a }}$ vez em quem somos, atribuir significado aos pais, pensar em quem queremos ser...

- Poderia descrever melhor o que o torna perfeito para você?

- Clichê por qual razão? Comente um pouco mais o que pensa, ok?!

- Aguardo ansiosa que termine o relato!

- Sei como é! Como é bom quando somos tragados por uma história que fica impregnada em nós... parece que a nossa vida vira um obstáculo para a leitura! - Leitura é assim: há livros e momentos de carregar pra todo lado, já outros de parada, lentidão, quando não evolui... insista!

- Vou pensar em alguma coisa para te indicar... precisa ter final feliz?

Nesses comentários o que se sobressai é a intenção de motivar os alunos a contar mais detalhes da história, desenvolvendo a estrutura narrativa. As ano- 
tações também visam a estimular o posicionamento crítico, articulando análise estrutural e percepção estética da obra. Não ficam de fora a experiência pessoal, as emoções e demais vivências relacionadas à experiência de leitura, traços particularmente valorizados pela docente. É ao propiciar esse espaço de autoconhecimento e de troca, em que se compartilham gostos e opiniões, que os alunos começam a exercitar o hábito da leitura e da escrita de um modo mais orgânico e articulado.

Posteriormente, o diário de leitura passou a ser instituído desde a primeira aula do ano. E, com ele, as práticas de leitura passaram a incluir maior variedade de textos, cabendo contemplar dois grupos de leitura: 1) gêneros curtos, reportagens, notícias e editoriais de revistas e jornais; 2) gêneros longos, romances e dramaturgia, epopeias e novelas. Manteve-se, todavia, a opção de livre escolha dos textos a serem lidos, intercalados durante o ano com duas ou três indicações para leitura de todos e discussão no grande grupo. Há, portanto, a alternância de escolhas - por parte do aluno e do professor - e formas de leitura variadas - tanto individual e coletiva quanto silenciosa e dramatizada -, ainda que prevaleçam as primeiras por estimular maior autonomia.

A avaliação se dá especialmente no aspecto qualitativo. Considera-se a dedicação semanal ao exercício de leitura e escrita e o quanto cada um está avançando no processo. Mais do que memorizar roteiros ou categorias, são estimulados a narrar sucintamente o que leram e, principalmente, o que foi que a leitura despertou neles: sentem-se instigados ou entediados? Recomendariam aos colegas ou não? Por qual razão? O foco é incitá-los a observar onde o texto ou o livro foi publicado, qual a opinião/enfoque do autor sobre o tema e qual a própria percepção sobre o que leram, relacionando o texto a discussões feitas na escola ou a vivências pessoais. Não é fixado o número de linhas a serem lidas ou escritas, mas, pela experiência, com o passar das semanas, as leituras e os registros naturalmente vão ganhando corpo.

\subsubsection{Avaliação do trabalho}

Passo agora diretamente à exposição da produção dos alunos, apresentando alguns registros rigorosamente como foram grafados. Serão apresentados nomes fictícios e a idade para situar unicamente o gênero e a faixa etária dos leitores/autores citados aqui. A concepção que norteou a escolha/indicação foi a de que qualquer texto, mesmo não consagrado, com intenção literária visível num trabalho da linguagem e da imaginação seria, num primeiro momento, adequado para a leitura e posterior análise por parte do aluno leitor (LEITE, 2012, p. 21). A leitura dos livros deveria partir da leitura das orelhas e da contracapa. Tal abordagem favorece que se formulem hipóteses sobre o conteúdo 
do livro a partir do título, da imagem, do autor. Também foi sugerido que avaliassem se o argumento de incitação à leitura da contracapa parecia exagerado ou adequado ao texto, se era possível estabelecer referências com outras obras do mesmo gênero, estilo ou autor etc. (MACHADO, 2007, p. 33-38).

Para a seleção, com frequência dois ou três mais iniciados da turma percorrem as prateleiras da biblioteca auxiliando os colegas. É interessante observar que, em geral, eles dispensam a ajuda do sistema de buscas eletrônico: se dirigem diretamente às estantes e começam a identificar seus setores de preferência. Retiram os exemplares e comentam, com sua linguagem naturalmente mais acessível: "Esse livro é a sua cara", "Essa autora entende a gente, saca!", "Morri de medo" e até um "Esse aqui você precisa ler porque mudou a minha vida”. Os relatos também deixam entrever essas conversas de corredor:

\section{Minha vida fora de série, de Paula Pimenta \\ “Vou começar a ler 'Minha vida fora de série' esta semana. \\ Pelas recomendações, sinto que vou AMAR esse livro! (:):-(;)"}

Helena, 13 anos

\section{Game of Thrones, de George R. R. Martin}

"De tanto meus amigos falarem sobre o livro "Game of Thrones" fui pesquisar, como não tenho condições por enquanto para compra-lo vou ver a série. Comecei a ver, é muito boa, por enquanto pelo menos... :)"

Beatriz, 13 anos

Uma vez que as escolhas são influenciadas pela mídia nacional e, com maior força, pela indústria cultural americana - não apenas a dos livros, mas a das demais formas de entretenimento, em especial a dos games, sites, séries e filmes -, os alunos em determinado momento também foram motivados a investigar livros que já existissem em suas casas e a buscar indicações junto a parentes e amigos próximos da família. Fugindo da padronização imposta por modismos e lançamentos do mercado editorial, puderam compartilhar descobertas:

Sonhos de robô, de Isaac Asimov

"Essa semana eu estava procurando um livro para ler em casa e achei um com uma capa dura e azul, velho e empoeirado, com as folhas amarelas e um pouco de mofo na primeira página. Mas não foi isso que me interessou nele, foi um nome escrito em dourado na capa: Isaac Asimov, e em baixo o titulo 'Sonhos do Robô' e achei o máximo meu pai ter um livro tão antigo assim em casa. E agora eu comecei a ler e descobri que foi o Isaac que inventou a palavra 'Robótica'. O livro fala de vários robôs, que não são aceitos pela humanidade, mas as primeiras lei colocadas no cerebro deles é que eles não devem machucar um humano, mas um 
desses robos não tem essa lei em $1^{\circ}$ lugar e as pessoas tem que achar ele, mas o problema é que ele é igual a todos os outros robôs de lá.”

Isabela, 13 anos

\section{Doador de memórias, de Lois Lory}

“Recebi uma indicação de um livro chamado o 'Doador de memórias', pelos amigos da minha mãe fiquei interessada pela história, que fala sobre uma pacada cidade onde os individos são sujeitos a gargos e varias regra, um unico individo é responsavel por guardar as memórias da sua cidade.

Aos 12 anos de idade cada criança é escolida para a profisão que irá seguir, e Jonas (principal personagem) e designado a ser um guardião de memoria... Estou entusiasmada para ler.”

Sofia, 14 anos

\section{Night Watch}

"Meu pai me deu outro livro de astronomia que ensina a como ver o céu com um telescópio, e li 4 página (mas o livro é enorme de tamanho e grossura!) Nestas páginas que lí, teve uma parte de perguntas de um jornal, e uma delas era se dava para ver onde os atronautas pousaram na lua, e o homem responde que pode, e logo abaixo diz que não. Muito confuso. Mas tirando isto, o livro é muito legal, ele te explica posições, dá dicas de como ver melhor os planetas, bem massa!

O problema é terminar de ler essa enciclopédia!”

Maria, 13 anos

Encontrar um livro que possui uma história na casa, receber um relato prévio de uma pessoa querida que apresente o enredo da obra indicada e até mesmo herdar uma enciclopédia que carrega consigo o gosto do pai pela astronomia são exemplos de como os livros puderam ganhar outros significados na vida desses adolescentes. Mais do que a série que todo mundo viu, esses livros são a obra que por alguma razão especial tornou-se parte do repertório de leitura um indivíduo em especial.

Libertar os alunos de uma escolha universal e impositiva trouxe outras surpresas, pois permitiu uma efetiva troca: os alunos passaram a recomendar leituras para a docente que, na medida de suas possibilidades, as realizou, tecendo comentários nos diários dos demais leitores desse autor. Mais abertos, os alunos também mostraram-se receptivos diante de sugestões de títulos. A ideia não era substituir suas preferências, mas agregar, inserindo junto ao repertório em formação outros estilos e formas de construção narrativa, motivando-os a subir alguns degraus na complexidade das tramas. Assim, se na mesa de cabeceira da 
professora circularam nomes como J. K. Rolling, Rick Riordan, Daniel Handler, John Green, Suzanne Collins e Veronica Roth, na de vários alunos chegaram autores como Umberto Eco, Edgar Allan Poe, George Orwell, Tolkien, Samuel Beckett, Ionesco, Machado de Assis, Jorge Amado, Clarice Lispector e Mia Couto.

\author{
Minha vida fora de série \\ "Como eu já tinha falado na outra semana... Terminei de ler Minha vida fora de \\ série 1, e já li a 2 temporada também! E profa do céu é M-A-R-A-V-I-L-H-O-S-O!! \\ Recomendo demais. \\ OBS: to aceitando indicações de livro. De amorzinho mesmo, hihihi. (:):-) \\ Não estou lendo nenhum livro no momento. Mas já vou ver algum para \\ ler!Gostei muito das dicas dos livros, profa! Obrigada (:)"
}

Samanta, 13 anos

\title{
Aprendiz de inventor, de Carrascoza
}

"PROFIIIII, comecei a ler o livro que a gente viu com você, e olha, eu achava que eu não ia gostar mas tô gostando! Sério! O livro é bem intrigante e a gente nem vê o tempo (e as folhas, devo comentar) passarem."

Ana, 13 anos

\section{Drácula, de Bram Stoker}

"Li mais um pouco do livro que a professora me emprestou, nunca li de verdade um livro, estranho, estou começando a gostar, é muito divertido este livro do Dracula.”

Raul, 13 anos

Após cada escolha, foi sugerido que os alunos lessem no mínimo 20 ou 30 páginas para se situarem na narrativa. Depois disso, se a leitura não fluísse, eram aconselhados a experimentar outros gêneros ou autores até encontrar algo que lhes agradasse. O registro das obras cuja leitura foi abandonada permitiu avaliar as dificuldades pessoais de leitores inexperientes que buscam uma narrativa linear tomada por cenas de ação. No outro extremo, permitiu igualmente reconhecer gostos mais refinados de leitores exigentes diante de obras que julgavam problemáticas:

\section{A última música, de Nicholas Sparks}

“Parei de ler 'A última música', não estava entendendo mais nada. Cada capítulo desse livro é um personagem falando e isso me deixa enrolada.” 


\begin{abstract}
Avalon high, de Meg Cabot
“Estou lendo um livro chamado ‘Avalon high' de Meg Cabot, já li algumas páginas mas não to gostando muito do livro, é meio ou totalmente sem emoção. Vou continuar lendo se eu não gostar pego outro.”
\end{abstract}

Mariana, 13 anos

O nome do vento, de Patrick Rothfuss

"Infelizmente eu não consegui passar das 100 paginas. O livro não me motivou muito, é uma história (até onde eu li) que não sai muito do lugar, e tem uma narração em $1^{a}$ pessoa (o que eu odeio).

O começo foi assim (não lembro os nomes dos personagens). O personagem principal, é dono de uma pousada/bar, e pelo o que eu percebi, tem um passado bem ativo. Certo dia recebe uma visita de um escriba, que pede informações sobre sua antiga vida (pelo que pareceu, o protagonista era uma lenda). Ele acaba aceitando e assim começa a contar. E é praticamente assim que o livro começa... li um pouco mais, mas não me animei. Mas, na minha opinião, é uma boa forma de começar uma história (e bem criativa). Emprestei o livro para um colega, talvez quando ele acabar eu me anime e leia de novo."

Aline, 13 anos

Análises como essas motivam discussões no grande grupo: por que a predominância dos thrillers de ação entre adolescentes? Qual o papel das séries e dos filmes no estímulo ao consumo de emoção? Qual o problema da narrativa em primeira pessoa? Que tipos de dificuldades acarreta? Problematizar alguns temas polêmicos colabora para o amadurecimento individual. Poucos foram os alunos que, decorrido algum tempo, permaneciam com uma mesma obra com efetiva dificuldade para avançar na leitura. Nesse caso, coube um acompanhamento maior da docente tendo em vista as dificuldades e gostos de quem se mostrava efetivamente começando na leitura de romances.

Os diários mostram-se úteis para levantar o que é significativo para esses jovens leitores, pois, conforme discutido, registram dificuldades, reações e relações estabelecidas (MACHADO, 2007). Enredos que contenham "muito sangue, palavrões, coisas nojentas", ou então em que "você fica tensa a cada minuto nas situações" eram constantemente citados por agradar nosso público, tanto o feminino quanto o masculino. Entre um número considerável de meninas houve também uma certa predisposição a dramas e histórias de amorzinho, mas não há como generalizar porque havia igualmente um grupo considerável das que detestavam esse gênero. Transcrevo a seguir o relato de três alunos que revelam um pouco dos interesses pessoais implicados nas escolhas: 


\section{Will \& Will, de John Green}

"O livro que eu estou lendo se chama Will \& Will do John Green (mesmo autor de A culpa é das estrelas). Até onde eu parei, ele falou um pouco da vida dele e sobre o seu pai. Eu espero gostar muito desse livro, pois me falaram que contava sobre um romance homossexual, então estou ansiosa para chegar a noite e eu poder ler.

PS: eu leio apenas de noite, por falta de tempo (tenho apenas 13 anos!).”

Júlia, 13 anos

\section{Cidades de papel, de John Green}

"O livro que eu tô lendo é muito baita e uma aventura e um romance já estou na metade dele. Mas olha ele ta meio repetitivo, por isso que eu to lerda.”

Mariana, 13 anos

\section{Jogos vorazes, de Suzanne Collins}

"Katniss vai atraz de Peeta, acha ele camuflado nas pedras e ela quase pisa nele pois a pedra que se camuflava estava no chão, ao encontralo repara que não está bem, tem um corte gigante em sua perna, ela o limpa tenta tratalo com o que sabe, não dá muito certo, mas ela consegue mantelo vivo e alimentalo.

Eles recomeçam o seu romance com uma beijo (aiii meu deus : ) mas obviamente que ele não fica melhor com isso mas pelo menos mais alegre. Eu tô muito puto pois Hamitch demorou muito para enviar algo para ajudalos, e se continuar assim Peeta vai acabar morrendo : ("

Gabriel, 13 anos

Enfatizo nos três casos a emoção que tentam expressar por meio de interjeição: "(aiii meu deus : )"; adjetivação: "é muito baita”, "Eu tô muito puto"; e de emoticons que frequentemente aparecem desenhados a caneta nos diários ou por meio de figurinhas adesivas, sinal claro da onipresença de outras mídias no cotidiano. Quanto à análise linguística, os diários são uma importante ferramenta para diagnosticar conteúdos a serem explorados em sala. Nos casos apresentados, os desvios da norma-padrão referem-se principalmente à pontuação e à colocação pronominal. Analisando cuidadosamente o que escrevem, notamos que os alunos acertam mais do que erram. Seus desvios, com relação à variante padrão, mais recorrentes concentram-se em dois aspectos: assinalar adequadamente a colocação pronominal e adequar a pontuação. Sobre o terceiro, note-se que, apesar de não usar hífen ou separar os termos, usando “encontralo" em vez de "encontrá-lo", os verbos foram conjugados adequadamente, em consonância com a pronúncia. 
A forma de intervenção adotada pela docente, nesses casos, foi sublinhar as palavras em desacordo para que o próprio aluno reflita, pesquise e adeque o que está em desacordo. A ajuda em casos mais recorrentes vem em sala, com exercícios de reforço a partir de necessidades reais observadas nos diários. Em comum entre os dois últimos alunos cujos diários foram citados é que não costumavam ler com frequência, mas após algum tempo e com alguma persistência se mostraram enredados pelas histórias, como revelam as cenas narradas, em que se alternam suspense, dor e paixão diante da sucessão de acontecimentos.

Permitir que os alunos façam sua própria seleção de livros não significa que não percebam diferenças ou deixem de agregar algum grau de complexidade ao que leram. Este, aliás, é o objetivo maior no longo prazo. Para tanto, são estimulados a refletir e a estabelecer comparações entre obras e autores, notando diferenças de estilo que implicam até no ritmo da leitura, como fica evidente no caso dos registros de quatro alunos reproduzidos a seguir:

\title{
O teorema Katherine, de John Green, e Árvore e folha, de Tolkien \\ "Essa semana comecei a ler os livros 'O teorema de Katherine' e 'Árvore e folha'. Bem eu realmente demoro para ler os livros de Tolkien porque é uma leitura complexa e 'pesada' porque ele é muito, muito detalhista. Já John Green, por mais que as pessoas achem 'romance' muito grudento e nojentinho (como eu achava) ele mostra que é totalmente ao contrário. Ele me fez gostar de romance! ROMANCE!!!”
}

Simone, 14 anos

\author{
A lenda dos guardiões, de Kathryn Lasky \\ “Essa semana comecei a ler 'A lenda dos guardiões' e eu não sei se você já viu \\ porque eu vi (milhares de vezes) e o livro só alimentou as esperanças de que um \\ dia eu vou ser uma coruja. \\ Bem, se você não conhece eu vou falar uma parte: o livro fala sobre corujas que \\ querem dominar o mundo e para impedir isso é criada uma 'liga' pessoas... quer \\ dizer, corujas que querem impedir que isso aconteça. \\ A literatura é bem infantil. Não é tão séria como 'O senhor dos anéis' é específico \\ para crianças. \\ Agora toda a vez que chego em casa em vez de pedir um irmão eu peço uma \\ coruja-duende chamada Eglantine." \\ Isabela, 13 anos
}

\section{O Hobbit, de Tolkien}

"Essa semana lí da página 165 até a 189 do livro 'O Hobbit'.

Essa parte fala de quando os anões são capturados pelos elfos da floresta, os mesmos que capturaram Thorin. Bilbo não foi pêgo pois botou o anel, mais seguiu os elfos para saber onde estavam levando os anões. 
O rei elfo prendeu eles porque os mesmos não queriam falar o que faziam alí, o único solto era o Hobbit.

Essas aventuras são sempre muito sombrias, pois nunca sabemos quem é do bem e quem é do mal.”

Ricardo, 13 anos

Divergente, de Veronica Roth

"Eu terminei o livro Divergente. Eu achei o final meio fraco, pois o autor não explica muito bem o que aconteceu. Como eu já havia mencionado. Eu achei a ideia de distopia (mundo que teve a forma de governo alterada radicalmente para 'pior') meio clichê (já presente em 'jogos vorazes') mas ao mesmo tempo interessante, pois pode ser considerada uma representação mais 'exagerada' da sociedade atual.”

Vicente, 13 anos

No primeiro trecho, uma aluna revela seu inesperado gosto por romances românticos, gênero que criticava nas exposições dos colegas por preferir as sagas épicas. Estas últimas, aliás, não passam despercebidas, tendo em vista que analisa o estilo detalhista e, convenhamos, por vezes cansativo, de Tolkien. Bem-humorada é a leitura de A lenda dos guardiões e seu flerte com a literatura infantil e a imaginação fantástica. Na citação seguinte, outro aluno desenvolve uma narração acerca de eventos ocorridos em O Hobbit. Ao destacar o lado sombrio da obra, expressa com suas palavras toda uma concepção de personagem que não se deixa aprisionar por um confortável maniqueísmo, aliás, esse é o lamento do leitor. Revela como é uma forma de escrita que gera ansiedade, desassossega quem o lê, o que considero positivo, por preparar quem o lê para outros tipos de desafios com a linguagem.

Os desvios da norma, nesse caso, são semelhantes aos que foram apontados anteriormente, tendo em vista que também seguem um padrão, como a acentuação de sílabas que ele considera tônicas, o emprego de pronomes e a pontuação um tanto inadequada. As obras e os debates permitem aos alunos internalizar nomenclatura crítica, estruturas arquetípicas recorrentes e a se tornar mais exigentes gradativamente, como é o caso da análise de Divergente. Este aluno tanto compreendeu o que seria um mundo pós-revolução, como percebeu que se tratava de uma mesma fórmula presente em outras sagas adolescentes: o messianismo de um redentor desajustado que salva um mundo imerso em caos, como ocorre no já citado Jogos Vorazes e em outras obras similares que leu.

Colocar em jogo a maturidade de leitores ainda mais proficientes e confrontá-los com novos desafios são estratégias para ajudá-los a seguir crescendo. $\mathrm{O}$ primeiro trecho a seguir é de um aluno que se dedica a altas literaturas, para em- 
pregar o termo de Leyla Perrone-Moisés, mas, após algum tempo, descobre que ainda não está preparado para alguns livros. O segundo, registro de uma aluna que se interessava por romances policiais e para quem a professora indicou $O$ nome da rosa, de Umberto Eco:

O Capital, de Karl Marx, O apanhador do campo de centeio, de Salinger, e O Festin dos corvos, de G. R. R. Martin

"Tô lendo 3 livros: O Capital, de Karl Marx, O apanhador no campo de centeio, de J. D. Salinger e O Festin dos corvos, de G. R. R. Martin, eu tô gostando de todos, mas O Capital é meio difícil...”

Marcos, 13 anos

O nome da Rosa, de Umberto Eco

“Comecei a ler o livro 'O nome da Rosa', escrito por Umberto Eco e publicado pela Folha de São Paulo. O livro narrado por Adson, na época um noviço, fala sobre sua estadia, acompanhando seu mestre, Guilherme de Baskerville, em uma abadia famosa na Itália. Lá, é pedido a Guilherme que investigue a morte de um dos monges. Estou gostando muito do livro, ele é de investigação, mas é diferente porque se passa em uma época muito religiosa, o que adiciona uma novidade em relação a outros livros do mesmo gênero.

ECO, Umberto. O nome da Rosa. São Paulo: PubliFolha, 2003.”

Roberta, 13 anos

Se um garoto de 13 anos não considerasse $O$ capital uma leitura difícil, realmente, deveríamos investigar a existência de um jovem com múltiplas habilidades. Com o passar das semanas, ele próprio abandonou a leitura, lamentando, em registro posterior, não conseguir concluí-la. Nesse caso, coube à docente ajudá-lo a reconhecer os grandes desafios que já se impunha, as leituras de clássicos que já realizava e a possibilidade de retomar Karl Marx daqui a alguns anos. Concentrado em uma única obra, Martin rendeu uma boa leitura. Também é digno de nota o que a aluna registra sobre sua primeira imersão em um romance de Umberto Eco. Leitora ávida de romances policiais contemporâneos, pôde estabelecer um contraponto com outra forma de escrita e paisagem, e em poucas linhas situa o leitor do seu diário no universo da obra de Eco. A anotação elaborada decorridos oito meses de registros também serve para revelar o aprimoramento de sua escrita que lhe permitiu resenhar com tanta propriedade.

Uma vez que o objetivo do trabalho passava por iniciar ou solidificar a formação de um cânone pessoal de gostos, esta revelou-se uma das partes mais significativas do trabalho. Na medida em que as leituras transcorriam, as anotações evidenciavam como a leitura transformou-se em hábito e mesmo em paixão que se fazia presente na vida de um número considerável de alunos. 
Envoltos nas tramas e próximos das personagens de modo muito passional, até mesmo seus registros passaram a exibir marcas mais evidentes de autoria, como a criação de suspense, humor, trabalho com o vocabulário e recomendação da leitura de um modo singular:

Minha vida fora de série, de Paula Pimenta

"O livro está ótimo, cheio de surpresas! Sabe aquela sensação que faz você não querer parar, e quando percebe já faz 1 hora que você está lendo, mas tem que parar porque tem que estudar para a prova? Então, é isso.”

Rafaela, 13 anos

Mar de monstros, de Rick Riordan

“Comecei a ler 'O mar de monstros' (segundo livro de Percy Jackson) e agora ele sai em busca de seu amigo mantido prisioneiro por um ciclope. Esse livro é ainda melhor que o primeiro e quero termina-lo mas não quero, porque quero saber o fim mas sempre que termino um livro eu fico tipo: 'E agora? O que vou fazer da minha vida?"”

Isabela, 13 anos

\section{O chamado do cuco, de J. K. Rowling}

“Esta semana terminei de ler o livro 'O chamado do cuco', escrito por Robert Galbraith (J. K. Rowling). Meu Deus, que final! Estou surpresa até agora com o jeito que acabou, valeu cada página. Quer saber qual é o final? Basta ler!”

Roberta, 13 anos

\section{Fallen, de Lauren Kate}

"Esta semana, terminei a releitura do livro Fallen, escrito por Lauren Kate e publicado pela Galera Record. Assim como na primeira vez em que li, amei o livro! Cada detalhe da história é tão perfeito que me dá vontade de viver o livro! Acho que, até agora, este é o melhor livro que eu já li! 'Tormenta' (segundo livro), lá vou eu!”

Carla, 13 anos

Analisando a produção decorrente das práticas desenvolvidas, destaca-se a diversidade de temas explorados nas leituras e o posicionamento que já se mostra crítico, querendo ensaiar seus próprios voos. Como qualquer outro trabalho desenvolvido em sala, há os alunos que se dedicaram e desenvolveram mais suas competências e habilidades de leitores. Nesse contexto, destaco a iniciativa dos alunos de criar outros espaços no diário de leitura. Prontamente aceitas, há propostas como esta: "Professora, eu gosto muito de frases. E conheço frases muito legais, por isso 
pela semana, gostaria de colocar frases lidas em livros ou vistas por mim. Bem, eu gostei. Mentira, amei essa frase [...]". Há ainda convites entusiasmados para compartilhar a leitura de outras produções escritas que ultrapassam a esfera do diário, especialmente fandom, blogs e poesias que não raro ganham as páginas como algo a mais, são encaminhados por e-mail ou chegam dentro de envelopes. Uma vez que cada anotação é lida e comentada, a troca e o diálogo são constantes.

\subsection{Considerações finais}

Tendo em vista o modelo de ensino de literatura constituído no Brasil - especialmente ao longo do último século - e a maneira como foi institucionalizado dentro dos estudos de língua portuguesa - com ênfase nas políticas de universalização do livro didático -, a adoção dos diários de leitura mostrou-se uma alternativa viável para o trabalho com obras como romances e epopeias paralelamente às aulas, conforme discutido ao longo do texto. Esta proposta mostra-se em consonância com o que está postulado nos $\mathrm{PCN}$, posto que estimula e permite uma mediação no primeiro contato com obras de maior densidade; corrobora para a formação do gosto, dando início aos cânones pessoais de leitura; insere no cotidiano escolar práticas de escrita com maior grau autoral; além de criar momentos para debater criticamente o que foi lido.

O diário, é bom ressaltar, não foi um gênero escolhido ao acaso. É uma forma confessional de escrita, como a carta, a autobiografia, o livro de anotações ou a agenda. Por séculos o diário representou a construção de um espaço íntimo, espécie de repositório de segredos privados. Hoje, tempo de blogs e aplicativos instantâneos de compartilhamento, os alunos são estimulados a se exibirem o tempo todo, publicando especialmente imagens, músicas e vídeos, sem que exercitem o senso crítico e as habilidades de escrita. Imergindo em um momento histórico com semelhantes particularidades, recursos e linguagens próprios, conceber uma forma de escrita que é pessoal, mas ao mesmo tempo compartilhada com o grupo, colabora para a constituição subjetiva desses sujeitos. Sua escolha passa até pelo caderno escolhido: grande ou pequeno, de bolso ou reciclado, encapado com jornal, tecido floral ou recortes de mangá, o diário de leitura permite que os educandos se apropriem de temáticas que lhes são caras, exercitem habilidade narrativa e analítica, criatividade e estilo. Talvez por essas razões, a estudiosa Annie Rouxel, ao pensar os aspectos metodológicos do ensino de literatura, tenha destacado a prática dos diários de leitura (e a lógica associativa) como a primeira opção entre as atividades destinadas a fazer emergir a subjetividade do aluno: "para que aprendam a escutar a si próprios” (ROUXEL, 2013, p. 22).

Como nem todos os cadernos são lidos integralmente a cada semana, tendo em vista os 45 minutos de duração da aula, os alunos ficam disputando o lugar na 
pilha sobre a mesa da professora, para assegurar que não seja o seu a receber apenas um visto. Ao receberem os diários, leem na biblioteca mesmo ou seguem lendo pelo caminho o que foi anotado, ficando desapontados quando não há anotações: "Professora, você leu mesmo?", indagam, posto que acostumados a comentários e indicações mais pessoais. A experiência parece ser tão significativa para alguns que, no início de 2015, duas alunas, uma do nono ano e outra atualmente na primeira série do Ensino Médio, espontaneamente procuraram a professora para perguntar se poderiam continuar a escrever o diário de leitura, trocando impressões de leitura semanalmente. Como não se trata mais da mesma professora de português de suas respectivas turmas, notamos como a aula de leitura e o diário de leitura ultrapassam a obrigação burocrática de assegurar uma nota.

Para encerrar este trabalho evoco Paulo Freire. O grande educador brasileiro fundamenta o que toma como saberes fundamentais à prática educativo-crítica ou progressista, deixando claro que "ensinar não é transferir conhecimento, mas criar as possibilidades para a sua produção ou construção" (FREIRE, 1996, p. 22). É na escola, na interação entre professor e aluno, quando se estabelecem vínculos de afeto, respeito e cumplicidade, que o aprendizado acontece, pois não há docência sem discência. Freire enfatiza que, apesar das diferenças que marcam esses sujeitos, eles não se reduzem à condição de objeto, um do outro. Dessa forma, "quem ensina aprende ao ensinar e quem aprende ensina ao aprender" (FREIRE, 1996, p. 23). E é essa troca incessante o que gostaria de destacar como característica maior das práticas de leitura e escrita desenvolvidas no trabalho exposto.

Contudo, a criação de comunidades de leitores e a implementação do diário de leitura em escolas da rede pública e mesmo privada são um grande desafio. Com três turmas com cerca de 25 alunos cada, a professora teve trabalho redobrado para dar conta de tudo o que os alunos escreviam, das próprias leituras de literatura e das demais aulas de língua portuguesa, pesquisa e extensão. Trata-se, portanto, de uma proposta que não é só pedagógica, mas eminentemente política. De assegurar meios materiais e condições dignas para que o professor possa desenvolver trabalhos particularizados junto a seus alunos. Um Estado que deseja assegurar ensino de qualidade não pode furtar-se ao compromisso de garantir condições adequadas de trabalho ao professor, condição sine qua non para bons resultados. Se o mundo é um enorme hipertexto, que todos tenhamos acesso às ferramentas para decodificá-lo, compreendê-lo e interpretá-lo, pois só assim ele fará sentido.

\section{Referências}

BRANDÃO, R. de O. Os manuais de retórica brasileiros do século XIX. In: PERRONEMOISÉS, L. O ateneu: retórica e paixão. São Paulo: Brasiliense: EdUSP, 1988. p. 43-58. BRASIL. Ministério da Educação. Secretaria de Educação Fundamental. Parâmetros 
Curriculares Nacionais: língua portuguesa, Brasília, DF, 1998.

BRASIL. Ministério da Educação. Secretaria de Educação Básica. Guia de livros didáticos: PNLD 2014: língua portuguesa: anos finais, Brasília, DF, 2013.

CANCLINI, N. G. Leitores, espectadores e internautas. São Paulo: Iluminuras, 2008.

COSSON, R. Círculos de leitura e letramento literário. São Paulo: Contexto, 2014.

DADOS estatísticos. PNLD. Fundo Nacional de Desenvolvimento da Educação.

Disponível em: <http://www.fnde.gov.br/programas/livro-didatico/livro-didatico-dadosestatisticos>. Acesso em: 29 jan. 2015.

FREIRE, P. Pedagogia da autonomia: saberes necessários à prática educativa. 25. ed. São Paulo: Paz e Terra, 1996.

GARCIA, W. Osman Lins educador. Outra travessia, Florianópolis, n. 4, p. 63-68, 1. sem. 2005.

LEITE, L. C. de M. Gramática e literatura: desencontro e esperanças. In: GERALDI, J. W. (Org.). O texto na sala de aula. São Paulo: Anglo, 2012. cap. 2.

LINS, O. Do ideal e da glória: problemas inculturais brasileiros. São Paulo: Summus, 1977. MACHADO, A. R. (Org.). Trabalhos de pesquisa: diários de leitura para a revisão bibliográfica. São Paulo: Parábola, 2007.

REIS, C. Ponderações sobre leitura: do mergulho ao surf. In: CONGRESSO

INTERNACIONAL DE LEITURA E LITERATURA INFANTIL E JUVENIL, 3., 2012, Porto Alegre. Anais... Porto Alegre: EdiPUCRS, 2012. Disponível em: <http://ebooks.pucrs. br/edipucrs/anais/IIICILLIJ/Trabalhos/Palestras/carlosreis.pdf>. Acesso em: 10 jan. 2015. RODRIGUES, N. C. Leitura nos ensinos fundamental e médio: reflexões sobre algumas práticas. Linguagem em (Dis)curso - LemD, Tubarão, v. 7, n. 2, p. 215-240, mai./ago. 2007. ROUXEL, A. Aspectos metodológicos do ensino da literatura. In: DALVI, M. A.; REZENDE, N. L. de; JOVER-FALEIROS, R. (Org.). Leitura de literatura na escola. São Paulo: Parábola, 2013. p. 17-33.

SAVIANI, D. O legado educacional do regime militar. Cad. CEDES, Campinas, v. 28, n. 76, p. 291-312, 2008. ISSN 0101-3262. DOI 10.1590/S0101-32622008000300002.

SOARES, M. Português na escola: história de uma disciplina curricular. In: BAGNO, M. Linguística da norma. São Paulo: Loyola, 2002. p. 155-177.

SILVA, V. L. T. A formação do leitor. In: . Leitura literária \& outras leituras: impasses e alternativas no trabalho do professor. Belo Horizonte: RHJ, 2009. p. 23-40. 